\title{
Educational Computer Games for Malaysian Classrooms: Issues and Challenges
}

\author{
Kamisah Osman ${ }^{1} \&$ Nurul Aini Bakar ${ }^{2}$ \\ ${ }^{1}$ Department of Educational Practice and Methodology, Faculty of Education, National University of Malaysia, \\ Selangor, Malaysia \\ ${ }^{2}$ Department of Chemistry, Faculty of Science and Mathematics, Education University of Sultan Idris, Perak, \\ Malaysia
}

Correspondence: Kamisah Osman, Department of Educational Practice and Methodology, Faculty of Education, National University of Malaysia, 43600 Bangi, Selangor, Malaysia. Tel: 60-3-89213858. E-mail: kamisah@ukm.my

Received: May 7, 2012 Accepted: June 7, 2012 Online Published: August 17, 2012

doi:10.5539/ass.v8n11p75

URL: http://dx.doi.org/10.5539/ass.v8n11p75

\begin{abstract}
This paper proposes the implementation of educational computer games in Malaysian classrooms. Local research has found that Malaysian students are familiar with computer games but the implementation of computer games as teaching and learning aids in the classroom has yet to be carried out. In reviewing this topic, the authors refer to the chemistry classroom as the case in point. The paper examines the issues and challenges faced by education stakeholders in designing and implementing educational computer games for Malaysian classrooms. Three main issues to be discussed here are the issues of: (i) the available educational computer games in the market and whether they are suitable to be used in Malaysian classrooms, (ii) the factors that ought to be considered in adapting and designing an educational computer game to be used in Malaysian classrooms and (iii) the barriers which hinder the implementation of educational computer games in Malaysian classrooms. The authors further propose an educational computer game design model for Malaysian classrooms. The model grasps the important issues and challenges discussed, depicting the factors to be considered during the planning and designing phases of an educational computer game. The paper concludes by encouraging local and international researchers to further explore the diverse scope of the computer game niche especially in the context of the local education system and chemistry education.
\end{abstract}

Keywords: chemistry education, educational computer game, educational game design, Malaysian classroom

\section{Introduction}

Today, the computer is not only a teaching aid instrument but is an important source of knowledge. The advanced technology of computers like the internet and computer simulation are imperatively driving changes in education, thus revolutionizing the function of computers in the classroom. According to Collins and Halversont (2010 p.18), "digital technologies such as computers, mobile devices, digital media creation and distribution tools, video games and social networking sites are transforming how we think about schooling and learning". It is important for teachers and educators to be able to adapt to this phenomenon, and this implies the need to implement new technologies in the teaching and learning process (Zamfir, 2008). Moreover, keeping head to head with the new generation of technology savvy students, the adaptation of the education system to the latest digital technologies is essential to accommodate students' interest and expectation. Computer as the dominant teaching aid instrument in schools, plays an important role in this matter. However, one thing that most students can relate to so far when they think about computers is not learning but playing computer games!

Computer games have influenced the lifestyle of most teenagers around the world. Thus, it is not surprising that education researchers are exploring the pedagogical potential of computer games (Squire \& Jenkins, 2003). Many scholars believe that educational computer games can motivate and increase students' focus on learning and simulate their higher order thinking (Facer, 2003; Gee, 2004; Prensky, 2001; Squire \& Jenkins, 2003). New areas of research such as games and learning (Sandford \& Williamson, 2005) and, digital-game based learning 
(Prensky, 2001) have been introduced to investigate how games might be used in the teaching and learning process. There is significant increase of research on educational computer games in recent years (Kirriemuir \& McFarlane, 2003). This may be in line with the boom of the computer game industry which has been valued at hundred millions of dollars per year (Buckingham \& Scanlon, 2005; Siwek, 2007). Research has demonstrated that the implementation of educational computer games in classrooms gave positive impact to student performances (Amory, 2010; Ketamo \& Kiili, 2010; Lee et al., 2004). However, in implementing educational computer games in classrooms, there are certain issues that should be considered especially in terms of social and cultural conditions of the education system where the classrooms are in.

In general, current literature on educational computer games focuses on the successful implementation of commercial computer games in the classroom teaching and learning process. These commercial computer games have, in fact, been labelled as educational by some scholars. This situation has triggered the question of whether the available educational computer games can be successfully implemented in Malaysian classrooms. This paper seeks to explore the possibility of implementing the available educational computer games in Malaysian classrooms. It reviews past and current literature on educational computer games and discusses the possibility of implementation in the context of the Malaysian education system. Three main issues to be discussed here are the issues of: (i) the available educational computer games in the market and whether they are suitable to be used in Malaysian classrooms, (ii) the factors that ought to be considered in adapting and designing an educational computer game for Malaysian classrooms, and (iii) the barriers to the implementation of educational computer games in Malaysian classrooms. The discussion of these issues also relates to the importance of considering the social and cultural conditions of the Malaysian education system in implementing educational computer games in Malaysian classrooms. Since there is a lack of information on the educational computer game domain in the Malaysian context, the paper aims to reveal to local and international educational researchers, educators and educational game developers, the issues and challenges in implementing and designing educational computer games for Malaysian classrooms.

\section{Educational Computer Games in the Malaysian Curriculum}

A study done by Rubijesmin (2007) investigates the experience of students from five schools in Malaysia and he found that $92 \%$ of the respondents have experienced playing computer games. The study shows that the students are no stranger to computer gaming. The implementation of educational computer games in the classroom is seen as rather aberrant though. This is because the educational game industry in Malaysia is still new. As reported by Roslina and Azizah (2009, p.296); "an interview with several educational game developers in Malaysia indicated that the field of education is still relatively new in local scenarios; hence, many localized studies are needed in order to generate more knowledge in educational games in the areas of educational games design, development as well as its effectiveness among our (Malaysian) students". The need for research and development in this area is in line with the Malaysian ICT Master Plan (finalized in 2001) which emphasizes on the integration of ICT in education and training programs (Lubis et al., 2009). The "long-term vision of the plan, Vision 2020, calls for sustained, productivity-driven growth, possible only with a technologically literate, critically thinking workforce, prepared to participate fully in the global economy of the $21^{\text {st }}$ century" (Lubis et al., 2009, p. 1382). Parallel with the current trend of the computer game phenomenon among teenagers and school students, the integration of it in the classroom is relevant and significant. In order to implement educational computer games in a classroom, it is essential to look upon the education system where the classrooms are.

The Malaysian education system is based on the national curriculum which is customised for public schools throughout the primary and secondary level. Teachers must adhere to the subject syllabus designed by the Ministry of Education. Therefore, every student in public schools is expected to acquire the same knowledge. Consequently, the education system is strongly dependent on the national curriculum. Thus, any intervention of pedagogical innovation in the classroom, in this case integrating an educational computer game, must take into account the necessity to follow the designated prospectus. The educational game, in a way should be a subject oriented game. Randel et al. (1992) support this idea by asserting that subject oriented educational computer games are more likely to show beneficial effects from gaming as compared to other types of educational computer games (Randel et al. 1992). In further reviewing the topic, the paper focuses on educational computer games for the chemistry subject.

\section{Educational Computer Games for Chemistry Teaching and Learning}

According to Habraken (1996), chemistry has usually been seen as a difficult subject by students. Habraken (1996) describes that students' perception towards the chemistry subject (as being difficult) is due to the traditional conceptual structure of the chemistry curriculum. To change this situation, it is essential for teachers 
to change their traditional way of teaching. Habraken (1996) stresses the need for interesting new approaches in the chemistry teaching and learning process to attract and engage students in order to change their negative perception. In addition, Osborne and Miller (1998) argue that the lack of variation in classroom activity during the teaching and learning process is one of the main issues in current science curriculums. Moreover, traditional and out-dated teaching approaches and methodologies strongly embraced by Malaysian chemistry teachers have worsened the situation, according to Abu Hassan (2003). Abu Hassan (2003) stresses that more interesting and attractive teaching aids need to be invented in order to assist student learning and boost their performance. Feasey (2005) supports this and believes that a creative science classroom depends on teachers' and students' expectation of new and interesting learning experiences. Educational computer games can be practical material to achieve a creative chemistry classroom. According to Ward et al., (2005, p.256); "games can offer many opportunities for pupils to learn both the knowledge of science and its associated vocabulary in an interesting way".

There is substantial literature that reports the use of chemistry educational computer games in the teaching and learning process. An annotated bibliography by Russel (1999) lists chemistry educational games published and marketed (majority in the USA) to be used by chemistry instructors and educators. There are 52 games listed by Russel (1999). From that amount, 26 are computer games while others are board, card or chemistry kit games. This shows significant efforts towards that the implementation of chemistry educational computer games in the teaching and learning process has already taken place. However, all of the games listed by Russel (1999) are targeted at tertiary students and are not suitable for chemistry lessons in schools. Other literature on the same topic, for example 'Periodic Table Games' by Martin (1997), 'FactGAME' by Ramette (1999), 'PLATO' by Smith and Chabay (1977), 'Egame' by Edmanson and Lewis (1999), 'Kinetics and Mechanism - A Game Approach' by Harsch (1984), 'CHeMoVEr' by Russel (1999) and 'The Old Prof Card Game' by Granath and Russel (1999) also show the inclination of chemistry education researchers towards creating educational games for tertiary level chemistry students. One point to be noted is that these educational computer games have been developed and designed by academicians and education researchers whose ideas are focused on the learning aspect as their primary aim and playing computer games as secondary.

In more recent years, literature has surfaced on educational computer games that are targeted at school level students (primary and secondary) and these games have been designed by big budget companies which focus on playing computer games first and learning second. Many scholarly reports have supported the positive impact of such games towards students' learning and how the implementation of educational computer games should be integrated into the classroom. Two popular educational computer games that have been commonly discussed in literature are Sim City and Civilization. For instance, Squire and Jenkins (2003), in their papers, report on how educational computer games such as Sim City and Civilization III have been successfully integrated in classroom activities. In Sim City, students are given the chance of role playing, where they learn about the social hierarchy, the economy and the politics of a population (a city - where they themselves have built). Civilization III allows students to lead a civilization from 4000BC to the present where they learn about how to "seek geographical resources, manage economies, plan the growth of their civilization and engage in diplomacy with other nation-states" (cited in Zamfir, 2008, p.12). It could be suggested that a similar genre of these games such as the CSI franchise games be implemented in chemistry classrooms where students can learn scientific knowledge, how laboratory work is done and scientific deduction carried out.

\section{Suitability of Educational Computer Games for Malaysian Classrooms}

Although students can learn a lot from games such as Sim City, Civilization and CSI, one should ask, are these computer games suitable for Malaysian classrooms? From the authors' point of view, being a multicultural country, Malaysia has a national curriculum which embraces the traditions and customs of its multi ethnic background. Hence, it is essential for educational computer games to be Malaysian oriented. Perrone (1994) emphasises that "to draw students into depth and complexity of a subject, we must look for topics that relate to students' lives". It is therefore important to present to the students material which they can relate to in order to engage them in the learning process. Educational computer games that are currently in the market were designed and produced by international gaming companies in favour of the social and cultural characteristics of the main targeted customers (for example Sim City and CSI- picture the lifestyle of Americans/Westerners; and Civilisation III - pictures the civilisation process of the western world).

Moreover, some education researchers have argued about the presence of learning values in commercial educational computer games. It has been pointed out that commercial educational computer games in the market often lack obvious cognitive values due to the emphasized entertainment value in the game (Hogle, 1996). On the other hand, there is also the view that educational games are neither fun nor engaging due to the emphasized 
educational value of such games (Hogle, 1996). It can be seen that if the games are too fun or entertaining, it can lose its educational attribute; viz. students will have fun playing but are hardly learning. In addition, it is argued that if the game is too educational, it will become boring and students will not be motivated to continue playing and ultimately will not learn anything. Charsky \& Ressler (2011, p.614) discuss this issue by asserting that (i) "if learning through games is meant to replicate children's more natural style of learning, then making them less like play and more like schoolwork will render them ineffective as educational tools" and, (ii) it is important "not (to) dilute the potential effectiveness of games by taking away one distinct attribute that gives them advantage play". According to Nor Azan and Wong (2009, p.269) "the educational effectiveness strategy (pedagogical element) needs to be integrated as a goal from the start of the design process". Education experts and game designers must work closely together to create an educational computer game that balances the learning and play element of the game.

From another viewpoint, most commercial games in the market are made primarily for entertainment purposes. Therefore, sometimes the product "conveys misinformation or foster misconceptions" (Squire \& Jenkins, 2003, p.12). According to Squire and Jenkins (2003,p.12) "Sim City, for example, exaggerates the mayor's power and ignores issues of race" and Civilisations III portrays a simpler version of how a civilisation is built. Having such disadvantages, it can be deemed inappropriate to implement the available educational computer games in the market into Malaysian classrooms. Some might argue that the misinformation could be used by teachers to challenge students to think critically and analytically. If that is the case, teachers would have to be given the skills in challenging students to think critically and analytically through computer games in classrooms. The issues provide a challenge to education stakeholders in adapting and/or developing educational computer games that are socially and culturally suitable for Malaysian classrooms.

\section{Factors to Consider in Adapting and Developing Educational Computer Games for Malaysian Classrooms}

Randel et al. (1992) review 68 research studies of educational computer games that were carried out from 1984 to 1991. In the review, Randel et al. (1992) explain that there are variations in research results where some (i) favour traditional instruction over educational games and some (ii) claim that there are no differences between traditional instruction and educational games on student performances. However, Randel et al. (1992) conclude that implementation of educational games in the classroom are consistently perceived as more interesting than traditional instruction. They further argue that the contradictory results (traditional instruction favoured over educational games/no difference between traditional instruction and educational games) are conceivably due to factors such as students' genders, students' background, game design and teachers' competence in implementing educational computer games as teaching and learning aids.

Jean et al. (1999) discuss how different genders react differently towards a game and how this affects students' performances while playing the educational game. According to Jean et al. (1999, p.207), "the findings provided evidence that PQ (Phoenix Quest - the game) appealed to girls because the protagonist was of their age and gender, and because the puzzles and searches were engaging throughout the game". Another research by Yen et al. (2011, p.279) also reveals the gender effect on game-based learning to promote intrinsic motivation. According to them, "females tended to be more perceptive than their male classmates regarding motivation, indicating stronger correlation to learning achievements". On the other hand, a research done by Hong and Liu (2003) rationalizes the effect of students' background and game design towards the overall students' performances while playing the game. According to Hong and Liu (2003), students who are considered to be expert gamers performed better compared to novice gamers. Besides, the difficulty and complexity of the game also influenced students' performances (Hong \& Liu, 2003).

Besides student gender, student background and game design factors, another important factor that needs to be considered in implementing and designing educational computer games for the classroom is the teachers' competence in applying the game to their teaching and learning process. Rubijesmin and Sheard (2009, p.177), through their research on Malaysian students' social skills while playing computer games in class report that "the important issues is not the object or technology used in teaching and learning, but how it is applied and diffused" by teachers. This shows the importance of teachers' competence in implementing educational computer games as teaching and learning aids in the classroom. However, Norizan et al. (2009), in their study of teachers' Information Technology (IT) literacy in Malaysia, report that the majority of Malaysian teachers are still novice users of IT. With this situation in mind, implementing educational computer games in Malaysian classrooms would be a challenging one. It is suggested that teacher development program and pre-service teacher curriculum be designed with an aim to equip teachers with information technology knowledge. Makki and Makki (2011, p.67) emphasize that "teacher educators must ensure that their students have sufficient technology skills, 
understand the advantages of using technology in the classroom, and can use it to improve the instruction".

It can be concluded here, that in order to design an educational computer game specifically for Malaysian classrooms, there are many factors that need thorough deliberation on the part of teachers and educators in adapting it, and, on the part of researchers and game designers in developing it for the Malaysian classroom. It is important that educational computer games to be implemented in the classroom are not biased towards certain groups of students or teachers.

\section{Barriers to Implementing Educational Computer Games for Malaysian Classrooms}

Rice (2007) summarizes six major barriers to implementing educational computer games in classrooms. According to Rice (2007), the barriers are negative perceptions toward video games as educational components; difficulty in providing state-of-the art graphics in educational video games, or a lack of adequate computing hardware in classrooms to run advanced video games; a school day divided by short class periods which hinder long term engagement in complex games; a lack of real world affordances; and a lack of alignment to state standards. Although the background of Rice's (2007) work was based on the situation in the United States of America (USA), the authors found it relevant to the situation in Malaysia. In relation to this, the authors will briefly discuss six major barriers in the context of Malaysian classrooms.

\subsection{Perceptions on Computer Games}

Although many researchers have proven that educational computer games can have positive impact on the teaching and learning process, there are also other opposing views. In Malaysia, computer games have long been (and still are) perceived as the medium of entertainment rather than of learning. And perhaps due to this, it is considered "too good to be true" and even impossible for some people (especially parents and teachers) to accept the educational part of computer gaming. Rice (2007, p.251) asserts that "perceptions hampering acceptance of even the best educational games for classroom use include a lack of understanding concerning the differences between arcade-style games... and cognitively viable modern games". In the stance where parents always disapprove of their children playing computer games and teachers are considered effective if the class is quiet and the students concentrate on what is being written on the blackboard and what has been said by teachers (chalk and talk), researchers and game designers are confronted with great challenges in selling their point of view.

\subsection{Unimpressive Educational Computer Games}

Quoting a student's point of view on computer games, "Games are made for one purpose: fun" (cited in Charsky \& Ressler, 2011, p.614).This clearly points out the essence of games in motivating and engaging players. However, uniting the elements of play and learning in a game, is not an easy task. With competition from the state-of-the-art commercial games in the market, educational computer games usually lose to the sophistication of big budget and popular games. Rice (2007) brought to our attention a situation when students in a class were informed that they were going to play a game. The students were very enthusiastic at first, but upon realizing that the game was not close to the sophisticated standard which they had been used to when playing computer games at home, the students were disappointed. They claimed that the game was lame and boring. Creating an educational computer game from scratch with the demand of such high level of production process is immensely challenging to local researchers and game developers (due to lack of resources, budget, skills, etc.).

\subsection{Lack of Infrastructure Capability}

Another problem which is of concern to researchers and game developers is the lack of infrastructure capability in Malaysian classrooms. Although it is possible for teachers to have computer access at school, it is highly doubtful whether every student is accessible to a computer for every class period (Rice, 2007). Perhaps the teaching and learning process could be conducted in a special place like a computer lab, but still, the computer lab in each school is usually accessible to only one or two classes at a time. Moreover, with the advanced standard of computer games nowadays, the capabilities of the machines to run the game sufficiently are also unpromising (Rice, 2007). As a result, researchers and game developers must take into considerations the type of game that they intend to create, whether it can be played by many students at the same time (one computer many players) or individual players (one computer - one player). What is the format of the game? Does it need special requirements (software or hardware) to run it? And how will the game be incorporated into the teaching and learning process in term of pedagogical and instructional aspects?

\subsection{Inflexible School Hours}

Rice (2007) noted the complex and challenging natures of good games that constantly motivate and intrigue players to fully engage in the game play. However, one aspect of the game that could be a disadvantage in the 
classroom is the time taken to finish the game. Typically, it takes hours and even days to complete one game. Taking into account the learning time provided for Malaysian schools; between 30-45 minutes per period, it is impractical to implement a time consuming game in the classroom. Perhaps researchers can design a game which has specific aims "so that learning objectives can be typically achieved within 30-45 minutes" (Rice, 2007, p.255). But, will the game be as complex and challenging for students to be motivated and be engaged in?

\subsection{Reality versus Virtual}

Rice (2007) presents the Affordance Theory proposed by Gibson in 1977 to explain the relationship between an entity and its environment. The Affordance Theory states that the world is perceived not only in terms of object shapes and spatial relationships but also in terms of object possibilities for action (affordances) - perception drives action (Affordance Theory). In the case of implementing educational computer games in the classroom, Rice (2007, p.256) describes that "within three-dimensional electronic environments, upon which many game instructional efforts are based, the current level sophistication is insufficient for highly advanced affordances".

Undeniably, virtual worlds created by educational computer games can simulate experiences that could benefit students but until what point should virtual world replace reality? However, the pros and cons of implementing educational computer games in the classroom need to be weighed by researchers and game developers in the course of decision making as far as computer games for ca. The lack of knowledge in terms of the Malaysian experience in developing and implementing educational computer games in the classroom challenges education stakeholders in determining until what point should virtual represent reality. The issue is subjective and depends upon other factors that also affect the implementation of educational computer games in classrooms.

\subsection{Aligning Games to Educational Standard}

The issue of aligning games to educational standard as discussed previously, is important as teachers are required to follow the national curriculum. For teachers to use educational computer games in the classroom, it is crucial for the game to be wrapped around the specific instructional content ("syllabus" here refers to only one syllabus) while at the same time it should be able to entertain and challenge students like conventional commercial games do. To align the game to educational standard, as suggested earlier, it has to be a collaboration between education experts as well as game designers/experts in the planning and designing phases of educational computer games.

\section{Educational Computer Game Design Model for Malaysian Classrooms}

This paper has discussed three issues associated with the idea of implementing educational computer games in the Malaysian classroom. The issues were i) the available educational computer games in the market and whether they are suitable to be used in Malaysian classrooms, (ii) the factors that need to be considered in adapting and designing an educational computer game to be used in Malaysian classrooms and (iii) the barriers which hinder the implementation of educational computer games in Malaysian classroom. From the discussion of these issues, the authors propose an Educational Computer Game Design Model (Fig. 1) which incorporates the issues and challenges in planning and designing an educational computer game for Malaysian classrooms.

The Educational Computer Game Design Model consists of three aspects of game design which are divided into two core components: Learn and Play. The two core components represent the elements of learning and playing in the educational computer game. A balanced integration of both components is essential in constructing a good educational computer game design. In the planning and designing phase of an educational computer game, the "Learn" component will be monitored by an education expert, while the "Play" component will be monitored by a game expert/designer. The education expert and game expert/designer need to work together in the planning and designing phases of the educational computer game, lending their expertise in developing an effective educational computer game for Malaysian classrooms.

The first aspect of game design is the game elements. Game elements refer to elements that form the base of the educational computer game. Fig. 1 shows the flow of how decision making is implied at the first stage of educational computer game planning and designing. The stage includes (i) the selection of syllabus and specific topic or learning outcome that will be the main background of the game and (ii) the selection of game design platform, proposition of the type of game (that will also be the background of the game) The aim of the two components of "Learn" and "Play" in the game elements is to achieve learning outcomes. Game Design Platform (GDP) refers to the tool or software that will be used to design the educational computer game. There are many game design tools/software available in the market, for example UNITY3D and Game Editor. The game design software will be the platform for the game expert/designer, while the national curriculum will be the platform for the education expert in planning and designing the game. Besides the decision making process discussed above, there are also other related elements; knowledge, challenge, engagement, and motivation, that need consideration 
in planning and designing the instructional and playing facets of the educational computer game.

Integration of both instructional and playing elements in the game will form the base of the game environment which comprises the teacher and students. In implementing an educational computer game in a classroom, it is crucial for the game to have distinctive roles for both teacher and students. The teacher is in charge of knowledge delivery of the game, taking roles such as mediator, facilitator or even opponent to the students who are the players of the game. It is through the gameplay that students will learn and achieve the learning outcomes. With the consideration of the game elements and game environment, the game design aspect is the crucial aspect in planning and designing the educational computer game.

The game design aspect in the model encompasses the factors for consideration in planning and designing the educational computer game. It is necessary for the education expert and game expert/designer to take into account the following factors in order to design an effective educational computer game:

Pedagogical factor - What is the teaching and learning strategy that will be incorporated into the game? And, what is the task and/or test that will be used to measure the learning outcome intended?

Gameplay design factor - What are the rules of the game? How complex will the game be? Is the background of the game appropriate to Malaysian classrooms?

Teacher factor - Does the teacher have the skills to implement and integrate the game into the teaching and learning process? Will the game match the teacher's expectation in term of the game as a teaching aid?

Student factor - Will the game be biased towards groups of students of different genders and background? Will the game match students' expectation in terms of the game as a learning aid?

Other factors - Will the available infrastructure be able to accommodate the game? How will the gameplay fit into the school period? How much will the game cost? Until what point should the virtual world in the game replace reality?

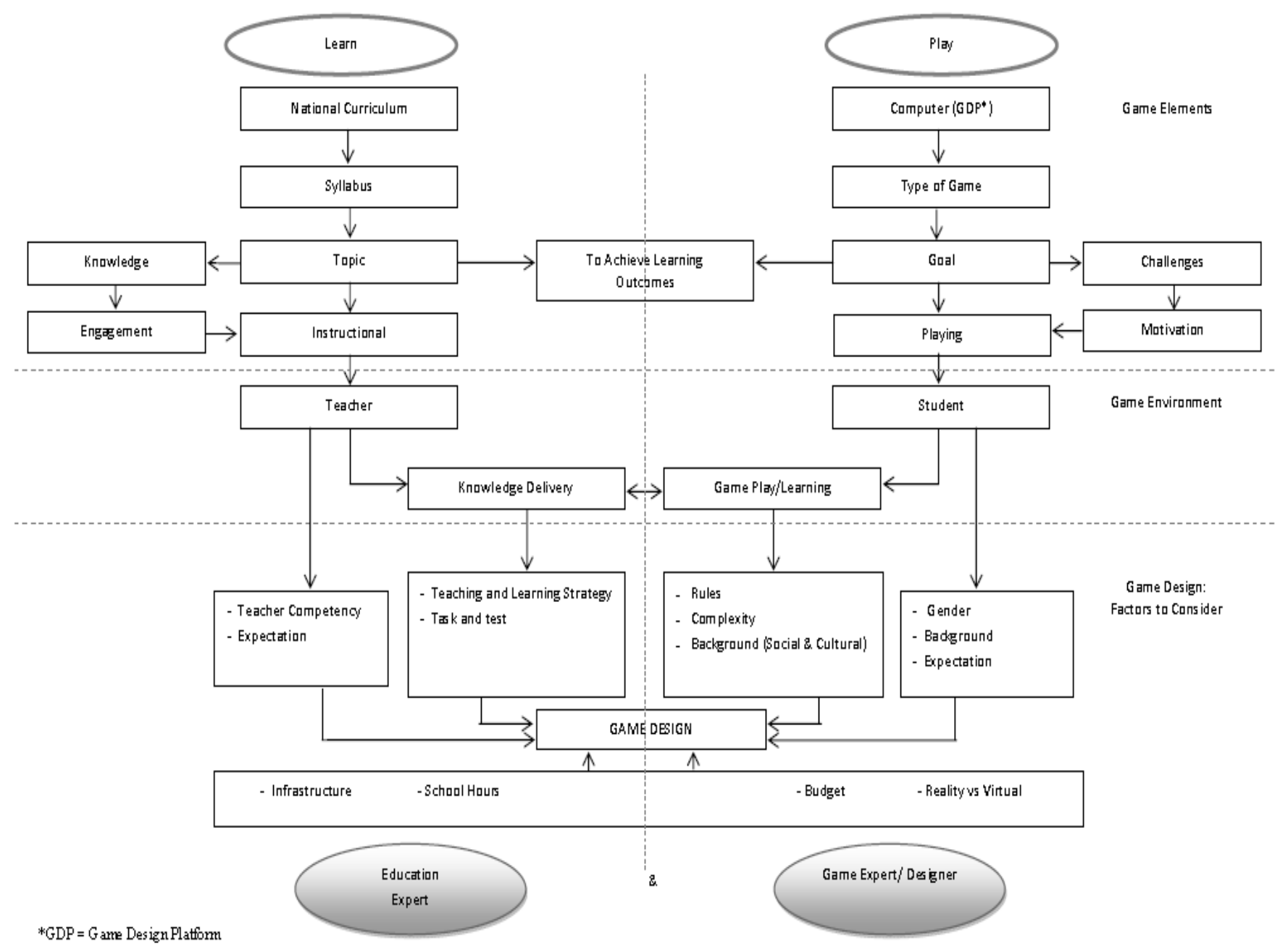

Figure. 1 Educational Computer Game Design Model 


\section{Conclusion and Recommendations}

So far in this paper, the authors have discussed three key issues that are challenges to researchers and game designers in implementing and developing an educational computer game for Malaysian classrooms. The issues are (i) the availability of educational computer games in the market and whether they are suitable to be used in Malaysian classrooms, (ii) the factors that need to be considered in adapting and designing an educational computer game to be used in Malaysian classrooms and (iii) the barriers which may hinder the successful implementation of educational computer games in Malaysian classrooms. In this paper, using chemistry classroom as the setting, the authors rationalize the incompatibility of available computer games to be implemented in Malaysian classrooms (despite reports of successful implementations elsewhere) and emphasize the need for designing specific and unique educational computer games in line with the Malaysian education system. It is clear that in adapting and developing educational computer games for Malaysian classrooms, there are many issues that educators, researchers and game developers need to consider especially those related to a specific region or community.

The integration of educational computer games in classroom teaching and learning process was, at first initiated due to its potential to motivate and engage students. Nevertheless, the computer game potentials are not limited to motivation and engagement factors. In today's world, the integration of computer games in the education system is much more significant since it has opened up various opportunities for students to gain knowledge and at the same time, learn multiple skills. Prensky $(2006 ; 2010)$ in his work, asserts that in the near future, computer games will be an important skill for students to acquire in the $21^{\text {st }}$ century. According to Prensky (2006), computer game is a powerful tool that allows students to develop complex $21^{\text {st }}$ century skills, and is a much better way than what the conventional teaching and learning process can achieve. Through playing computer games, students will learn to think critically, to solve problem, and to be creative and be innovative in order to finish the game. Computer games also gave space for students to communicate and collaborate with their friends and fellow players. Through computer gameplay, they can effectively learn career and life long learning skills such as flexibility, adaptability, initiative, self-direction, leadership and responsibility. In fact, the significance of computer game integration as an integral part of students' career and life long learning skills can be seen through the current trend in the professional arena. Besides just being entertainment and leisure activities for students to kill time, computer games are now part of professional development training in professional fields such as medical, military and engineering (Prensky 2006). For instance, medical doctors are now able to practice performing surgical operations via computer game simulations so that they can master the usage of mechanical medical devices; soldiers undergoing battle field training are now able to be trained via virtual 3D computer game simulation of various battle field situations and; aircraft pilots have long been using computer simulations during their training. These demonstrate that computer games can be mediums for professional skills training. Thus, integration of computer games in school education can give students the early introduction and familiarity to their later professional life.

In developed countries such as the USA and the UK, the integration of computer games in the education system is a serious effort, where in some cases even specific game based learning curriculum has been built to accommodate the implementation of computer games in the classroom. This education system transformation was made possible because of the extensive research and development efforts done by education researchers, educators and educational game developers. In the context of Malaysia, this effort is still in an early stage and the need for research and development of educational computer games that suit Malaysian educational setting is critical. This paper represents an initial endeavor in exploring the idea of educational computer game integration into the Malaysian education system. Obviously there is a huge gap of information that needs to be filled by education researchers and educators, as well as game developers especially in the context of chemistry education. Research should be done to explore chemistry education under the diverse scope of the educational computer game niche. Extra endeavors by local education researchers, educators and educational game developers are essential to generate more knowledge in the area of educational computer games in the country.

\section{References}

Abu Hassan, K. (2003). Pengajaran - pembelajaran kimia di sekolah menengah: ke manakah arah tujunya? Paper presented at Seminar Memperkasakan Sistem Pendidikan, Universiti Teknologi Malaysia, Johor Bharu.

Affordance Theory. In Learning Theories Knowledgebase. Retrieved January 3, 2011, from http://www.learning-theories.com/affordance-theory-gibson.htmlhttp://www.learning-theories.com/affordan ce-theory-gibson.html

Amory, A. (2010). Learning to play games or playing games to learn?: a A health education case study with 
Soweto teenagers. Australiasian Journal of Educational Technology, 26, 810-829.

Buckingham, D., \& Scanlon, M. (2005). Selling learning: towards a political economy of edutainment media. Media, Culture \& Society, 27, 41-58. http://dx.doi.org/10.1177/0163443705049057

Charsky, D., \& Ressler, W. (2011). "Games are made for fun”: lessons Lessons on the effects of concept maps in the classroom use of computer games. Computers \& Education, 45, 604-615. http://dx.doi.org/10.1016/j.compedu.2010.10.001

Collins, A., \& Halversont, R. (2010). The second educational revolution: rethinking education in the age of $\begin{array}{llllll}\text { technology. Journal of Computer Assisted Learning, 26, } & \text { 18-27. }\end{array}$ http://dx.doi.org/10.1111/j.1365-2729.2009.00339.x

Edmanson, L. J., \& Lewis, D. L. (1999). Equilibrium principles: a game for students. Journal of Chemical Education, 76(4), 502. http://dx.doi.org/10.1021/ed076p502

Facer, K. (2003). Computer games and learning: why do we think it's worth talking about computer games and learning in the same breath? Retrieved from http://www.futurelab.org.uk

Feasey, R. (2005). Creative science. London: David Fulton Publisher.

Game Editor. Retrieved January 12, 2011, from http://www.game-editor.com

Gee, J. P. (2004). Learning by design: games as learning machines. Interactive Educational Multimedia, 8 , $15-23$.

Granath, P. L., \& Russel, J. V. (1999). Using games to teach chemistry: the old prof card game. Journal of Chemistry Education, 76(4), 485-486. http://dx.doi.org/10.1021/ed076p485

Habraken, C. L. (1996). Perceptions of chemistry: why is common perception of chemistry, the most visual of sciences, so distorted? Journal of Science Education and Technology, 5, 193-201. http://dx.doi.org/10.1007/BF01575303

Harsch, G. (1984). Kinetics and mechanism - a games approach. Journal of Chemical Education, 61(12), 1039-1043.

Hogle, J. G. (1996). Considering games as cognitive tools: in search of effective edutainment. University of Georgia.

Hong, J., \& Liu, M. (2003). A study on thinking strategy between experts and novices of computer games. Computers in Human Behavior, 19(2), 245-258. http://dx.doi.org/10.1021/ed061p1039

Jean, J. D., Upitis, R., Corina, K., \& Young, J. (1999). The story of phoenix quest: how girls respond to a prototype language and mathematics computer game. Gender \& Education, 11(2), 207-223. http://dx.doi.org/10.1080/09540259920708

Ketamo, H., \& Kiili, K. (2010). Conceptual change takes time: game based learning cannot be only supplementary amusement. JI. of Educational Multimedia and Hypermedia, 19, 399-419.

Kirriemuir, J., \& McFarlane, A. (2003). Use of computer and video games in the classroom. Paper presented at Digital Games Research Conference, Universiteit Utrecht Netherlands.

Lee, J., Luchini, K., Michael, B., Norris, C., \& Soloway, E. (2004). More than just fun and games: assessing the value of educational video games in the classroom. Paper presented at Conference on Human Factor in Computing System, Vienna, Austria.

Lubis, M. A., Ariffin, S. R., Ibrahim, M. S., \& Muhamad, T. A. (2009). Teaching and learning process with integration of ICT: a study of smart schools in Malaysia. WSEAS Transactions on Information Science and Applications, 8(6), 1380-1390.

Makki, B., \& Makki, A. (2011). Comprehensive survey of instructional technology integration into educational technology. Recent Advances in Computers, Communications, Applied Social Science and Mathematics, 63-68.

Martin, J. S. (1997). Periodic table games. Journal of Chemical Education, 74(3), 346-347. http://dx.doi.org/10.1021/ed074p346.2

Nor Azan, M. Z., \& Wong, S. Y. (2009). History educational games design. Proceeding of International Conference on Electrical Engineering and Informatics, Selangor, Malaysia.

Norizan, A. R., Mohamed, A. E., Ramlee, M., \& Maimun, A. L. (2009). IT literacy of language teachers in 
Malaysian technical schools. Paper presented in $5^{\text {th }}$ WSEAS/IASME International Conference on Educational Technologies (EDUTE '09). La Laguna, Spain.

Osborne, J., \& Miller, R. (1998). Beyond 2000: science education for the future. London: Kings College Publications.

Perrone, V. (1994). How to engage students in learning. Educational Leadership, 51(5), 4-7.

Prensky, M. (2001). Digital game-based learning. New York: McGraw-Hill.

Prensky, M. (2006). Don't Bother Me Mom - I'm Learning. Minnesota: Paragon House.

Prensky, M. (2010). Teaching Digital Natives: Partnering for Real Learning. California: Corwin.

Ramette, R. W. (1999). FactGAME. Journal of Chemical Education, 74(4), 346-347. http://dx.doi.org/10.1021/ed074p347

Randel, J. M., Morris, B. A., Wetzal, C. D., \& Whitehill, B. V. (1992). The effectiveness of games for educational purposes: a review of recent research. Simulation \& Gaming, 23, 261-276. http://dx.doi.org/10.1177/1046878192233001

Rice, J. W. (2007). New media resistance: barriers to implementation of computer video games in the classroom. JI. of Educational Multimedia and Hypermedia, 16(3), 249-261.

Roslina, I., \& Azizah, J. (2009). Educational games (eg) design framework: combination of game design, pedagogy and content modelling. Paper presented at International Conference on Electrical Engineering and Informatics, Selangor, Malaysia.

Rubijesmin, A. L. (2007). Understanding Malaysian students as gamers: experience. Paper presented at Conference on Digital Interactive Media in Entertainment and Arts, Perth, Australia.

Rubijesmin, A. L., \& Sheard, J. (2009). Social skills among students while playing computer games in class: a case study in malaysia. Paper presented at International Conferences on Future Computer and Communication, 177-181, Perth.

Russel, J. C. (1999). Using games to teach chemistry: CHeMoVEr Board Game. Journal of Chemical Education, 76(4), 487-488. http://dx.doi.org/10.1021/ed076p48

Sandford, R., \& Williamson, B. (2005). Games and Learning. NESTA Futurelab.

Siwek, S. E. (2007). Video Games in the $21^{\text {st }}$ century: Economic Contributions of the US Software Entertainment Industry. Entertainment Software Association Report, United States of America.

Smith, S. G., \& Chabay, R. (1977). Computer games in chemistry. Journal of Chemical Education, 54(11), 688-689. http://dx.doi.org/10.1021/ed054p688

Squire, K., \& Jenkins, H. (2003). Harnessing the power of games in education, InSight, 3, 5-33.

UNITY3D. Retrieved January 16, 2011, from http://www.unity3d.comhttp://www.unity3d.com

Ward, H., Roden, J., Hewlett, C., \& Foreman, J. (2005). Teaching science in the primary classroom: a practical guide. London: Paul Chapman Publishing.

Yen, J., Wang, J., \& Chen, I. (2011). Gender diffrences in mobile game-based learning to promote intrinsic motivation. Recent Reseacrhes in Computer Science, 279-284.

Zamfir, A. (2008). Impact of using applications in education on teaching- learning process. Paper presented at $7^{\text {th }}$ WSEAS International Conference on Applied Computer \& Applied Computational Science (ACACOS '08), Hangzhou, China. 